\title{
Challenges \& Suitability of TESL at the College Level in Bangladeshi Context
}

Kamrul Hasan and Mohd. Moniruzzaman Akhand

\begin{abstract}
This paper presents the result of a study about teaching English to Bangladeshi college students. It analyses the problems faced by Bangladeshi English teachers, including methodological problems and expertise problem. The shifting from grammar based to communicative approach has produced acute problems of expertise in the field, resulting in inefficiency of the classroom instructors and lack of appropriate resources for language teaching. In response to the problems, this paper also discusses CLT methodology and considers the suitability of the Content-Based Approach (CBA) in Bangladeshi context. It then tries to uphold a balanced curricular and pedagogical suggestion for making language teaching more effective, arguing that blending of two approaches, CLT and CBA, can help English language teachers achieve maximum learning among students.
\end{abstract}

Key Words: Communicative Language Teaching (CLT), Content-based Approach (CBA), Curriculum development

\section{Introduction}

The history of English language in Bangladesh is a long one. It can be traced to the $18^{\text {th }}$ century when the British people first came to this subcontinent. Since then the people of this country have been striving to gain command of the English language in order to communicate with people who share the lingua franca. Invariably, English now is an internationally shared language, which further necessitates learning of English to the Bangladeshi people, and its learning must be updated with our changing needs in a globalized world.

There was a time in Bangladesh when students who graduated from the discipline of English Literature or English Language had no alternative other than to go into the teaching profession. But English graduates from literature or language are increasingly associated with a range of other sectors like banking and the newly established call centres. Even those who want to immigrate to the West need to sit for proficiency tests like the International
English Language Testing System (IELTS). The avenues where English Language Teaching (ELT) is required are increasing year after year in Bangladesh.

For the language teaching methodology, ELT practitioners in Bangladesh followed GrammarTranslation Method (GTM). The shift in the paradigm from GTM to Communicative Language Teaching (CLT) occurred around the year 2001. And now it is the official government education policy. This by no means was unique to Bangladesh because Korea already adopted this methodology (Li, 1998) and China also followed suit (Yu, 2001). The driving force for change seems to arise from the notion that traditional method has failed and is wrong whereas CLT will succeed and is right. Now-a-days, it is difficult to imagine any practitioner, anywhere, arguing against this though there have been criticism from Korea, Japan, Hong Kong, etc. A large number of teachers implement this in their teaching practice, and where this has not been implemented 
yet, there is a pressing urge to move to this direction. However, whether after almost half a century of influence, the CLT, which was basically formed and flourished in the Western context, still remains the model of a paradigm to the Asian students, is open to question. Given the dynamic features of CLT, it seems necessary to investigate the current status of the use of CLT in an English as Second Language (ESL) context like Bangladesh. The majority, that is, more than $95 \%$ of the current teachers of college level are the product of GTM. Now, they are also not very much acquainted as well as trained in newly introduced CLT. But the paradox is that they are now to teach their students CLT- oriented English curriculum as a part of their teaching. English teachers face many awkward situations, especially in case of the 'feedback' and 'assessing final-product' that aggravate their frustrations.

\section{Theoretical Background}

\section{Communicative Language Teaching}

The need for learning English as L2 emerges in Bangladesh from the necessity of communication in the international arena. The origins of CLT can be traced in the changes in the British language teaching tradition dating from the late 1960's (Richards and Rodgers, 2001). The work of the Council of Europe; the writings of Wilkins, Widdowson, Candlin, Christopher Brumfit, Johnson Keith, and other British applied linguists on the theoretical basis for communicative or functional approach to language teaching; the rapid acceptance of these new principles by British language teaching specialists, curriculum development centres, and government gave prominence nationally and internationally to what came to be referred to as the Communicative Approach or simply Communicative Language Teaching (Richards and Rodgers, 2001).

The CLT approach views language as a tool for communication. The focus of linguistic theory is to characterize all the abstract abilities that speaker possesses in order to communicate. Another linguistic theory of communication mostly cited in CLT is Halliday's functional account of language use: "Linguistics...is concerned...with the description of speech acts or texts, since only through the study of language in use are all the functions of language, and therefore all components of meaning, brought into focus" (Halliday, 1970). Another theorist frequently cited for his views on the communicative aspect of language is Henry Widdowson who emphasized on the communicative acts underlying the ability to use language for different purposes. Canale and Swain (1980) provide a more pedagogically influential analysis of communicative competence in which four dimensions are identified: (1) Grammatical competence, which refers to what Chomsky (1965) calls linguistic competence and what Hymes (1972) stated as what is "formally possible". This is the domain of grammatical and lexical capacity; (2) Sociolinguistic competence, which refers to an understanding of the social context in which communication takes place, including role relationships, the shared information of the participants, and the communicative purpose for their interaction; (3) Discourse competence, which refers to the interpretation of individual message elements in terms of their interconnectedness and of how meaning is represented in relationship to the entire discourse or text; and, (4) Strategic competence, which refers to the coping strategies that communicators employ to initiate, terminate, maintain, repair, and redirect communication (cited from Richards \& Rodgers, 2001). Bachman (1991) elaborates Canale and Swain's extension of Hymesian model of communicative competence. Celce-Murćia, Dörnyei, and Thurell (1997) in turn extend the Bachman model.

In CLT, the theory of learning lies on some principles as communication principle, task principle and meaningfulness principle. Communication principle involves activities that engage real communication and promote learning. Task principle includes activities that encourage language, which is used for carrying out meaningful tasks, and promote learning (Johnson, 1982). Finally, meaningfulness principle emphasizes on the language that is meaningful to the learner and supports the learning process. Johnson and Littlewood (1984) also cited an alternative learning theory-a skill-learning model of learning. According to this theory, skill 
development bears the mark of the acquisition of communicative competence in a language. Thus the objective of CLT is to enhance the communicative competence in a learner.

For CLT, the functional-notional syllabus is the model syllabus that is either followed or adapted for the curriculum. The functional-notional syllabus has the following features:

1. Learning tasks should be associated with the real world

2. Every day, real-world language should be taught

3. Receptive activities on the part of the learners are emphasized before rushing them into premature performance

4. Communication will be intrinsically motivating

5. It enables a spiral curriculum to be used which reintroduces grammatical, topical and cultural material

6. It provides for the widespread promotion of foreign language courses

To implement the theories and the curriculum in a classroom, a teacher plays a very intricate role in the CLT. He/She has to be a facilitator and initiator of activities, sometimes manager of the classroom tasks, promoter of communication, advisor, monitor, co-communicator and needs analyst for the learners. Since the teacher's role is less dominant than in a student-centred method, students are seen as more responsible managers of their own learning. Regarding the classroom activities, they can be either text-based or task-based. Text-based activities are mainly drawn from realia that consists of analysis, comprehension and paraphrasing. Task contains role-plays, simulations, language-games etc. Littlewood (1981) classifies activities into two - (a) pre-

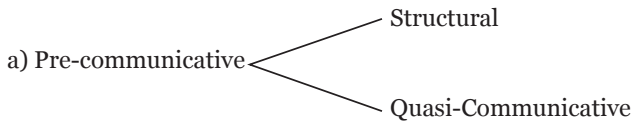

b) communicative

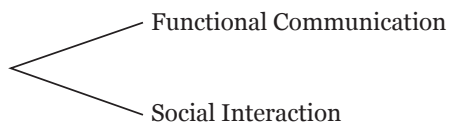

The methodological procedures underlying the texts reflect a sequence of activities in the above figure include that teaching points are introduced in dialogue form, grammatical items are isolated for controlled practice, and then freer activities are provided. Pair and group work is suggested to encourage students to use and practice functions and forms. This serves for freer practice activity that initializes real-life communication that engages communicative competence of a learner. CLT appealed to those who sought a more humanistic approach to teaching, one in which the interactive processes of communication received priority, involving the integration of different language skills whereas Content-based Approach (CBI) involves teaching around the content or information of students' learning.

\section{Content-based Approach}

Content-based approach to teaching language is focused around the content or information that students will acquire, rather than around the linguistic or other type of syllabus. Krahnke (1987 p. 65) provides the following definition: "It is the teaching of content or information in the language being learned with little or no direct or explicit effort to teach the language itself separately from the content being taught". New York Times columnist and linguistic pundit William Safire addresses it in one of his columns in 1998 and states:

If any word in the English language is hot, buzz worthy and finger-snappingly with it, surpassing even millennium in both general discourse and insiderese, that word is content. Get used to it, because we won't soon get over it. (NYT, August 19, 1998).

Like CLT, content-based teaching language also highlights the communication where there will be an ideal situation for second language learning in which the subject matter of language teaching is neither grammar nor function nor some other language based unit of organization, but content, i.e. subject matter outside the domain of language.

The content-based approach to language teaching basically emphasizes the teaching of a language 
focusing on reading and writing in all subject areas in the curriculum, and not merely in the subject called 'English Language'. Likewise, language skills should also be taught in the content subjects and not left exclusively for the English teacher to deal with. This report influences American education as well, and the slogan "Every teacher, an English teacher" becomes familiar to every teacher (Richards \& Rodgers, 2001).

Content-based teaching is based on the two central principles:

1. People learn a second language as a means of acquiring information, rather than as an end in itself.

2. Content-based teaching better reflects learners' needs for learning a second language.

According to Brinton et al. (1989), "The use of informational content which is perceived as relevant by the learner is assumed by many to increase motivation in the language course, and thus to promote more effective learning”. The learning in CBA emphasizes that "People learn a second language most successfully when the information they are acquiring is perceived as interesting, useful, and leading to a desired goal" (Richards \& Rodgers, 2001). It is also seen that language learning becomes easier and more fruitful when learners focus on something other than language, such as ideas, issues, opinions, experiences, events etc. Thus, "the student can most effectively acquire a second language when the task of communicating with someone... about some topic... which is inherently interesting to the student" (D’Anglejan \& Tucker, 1975). For example, Geography might be the first choice of subject matter. Geography is "highly visual, spatial and contextual; it lends itself to the use of maps, charts, and realia, and the language tends to be descriptive in nature with use of the 'to be', cognates and proper names" (Stryker and Leaver, 1993). The content that stimulates invigorating interests in the learner may provide the starting point for developing a syllabus. The schematic knowledge of students is also taken into account in the content-based teaching. This principle views learner not as a blank paper to be filled with information. Rather, they are viewed under Vygotsky's philosophy where the learners are seen as 'constructivists' who construct knowledge befitting acquired knowledge with the schema instead of learning them blindly.

To attain the object, therefore, the design of syllabus is crucial. The content-based model uses syllabus that is referred to as a topical syllabus. In this case, the example of Free University of Berlin can be mentioned (Richards \& Rodgers, 2001). Their syllabus consists of a sequence of modules spread over the academic year. The topical themes of the modules are:

i. Drugs

ii. Religious Persuasion

iii. Advertising

iv. Drugs

v. Britain and the Race Question

vi. Native Americans

vii. Modern Architecture

viii. Microchip Technology

ix. Ecology

x. Alternative Energy

xi. Nuclear Energy

xii. Dracula in Myth, Novel, and Films

xiii. Professional Ethic

The modules are designed and sequenced so that they "relate to one another so as to create a cohesive transition of certain skills, vocabulary, structures, and concepts" (Brinton et al., 1989). Krashen's input hypothesis should also be kept in mind while compiling topics for the language class.

Mohan (1986) identifies an approach for contentbased ESL instruction which is built around the idea of knowledge structures. This takes into account of a curriculum which is based on a framework and schemas. The framework consists of six universal knowledge structures, half of which represent specific, practical elements (Description, Sequence, and Choice) and the other half of which represent general, theoretical elements (Concepts/ Classification, Principles, and Evaluation) (Mohan, 1986). For the content-based approach the materials are crucial as both the teaching process and the 
learning process are centred on the materials. So, the materials that facilitate the language learning are used typically with the subject matter of the content course. For this reason, graded materials are recommended to utilize in the class. Hence, both teachers and learners play key role in the teachinglearning process. Content-based language teaching is in the "learning by doing" school of pedagogy (Richards \& Rodgers, 2001). So, the learners adopt an active role in the classroom interpreting the inputs and increasing the tolerance of ambiguity. Similarly, the teachers keep the context and comprehensibility in the foremost and apply empathy in selecting and adapting authentic materials.

For the secondary and higher secondary level, content-based teaching can be implemented through (a) theme-based approach and (b) adjunct approach (Richards \& Rodgers, 2001) -

a) Theme-based approach: An example of this approach is described by $\mathrm{Wu}$ (1996) in a programme prepared for ESL students in an Australian high school. Topics were chosen primarily to cater to the widest variety of students' needs and interests. Linguistic appropriateness was another factor taken into account when choosing topics as some involved more technical terms and complex grammatical constructions. The topics were also chosen for relevance to the Australian sociopolitical and cultural climate. Topics that fulfilled these criteria included multiculturalism, the nuclear age, sports, the Green movement, street kids, and teenage smoking ( $\mathrm{Wu}, 1996)$.

b) Adjunct approach: This approach focuses on science. Both the ESL teaches and the science teachers are involved in this approach. The adjunct approach focuses on the following:
i. Understanding specialized science terminologies and concepts
ii. Report writing skills
iii. Grammar for science
iv. Note-taking skills (Wu, 1996)

Content-based approach, thus, is widely used in variety of settings because of its adaptability. The advocates of this approach claim it to be one of the most successful programmes because of its unlimited opportunities for both teachers' and students' interests and needs. Brinton et al. (1986) observe:

"In content-based approach, the activities of the language class are specific to the subject being taught, and are geared to stimulate students to think and learn through target language. ....For example, it employs authentic reading materials which require students not only to understand information but to interpret and evaluate it as well. ....In this approach students are exposed to study skills and learn a variety of language skills which prepare them for a range of academic tasks they will encounter" (Brinton et al., 1986).

\section{Methodology}

All the teachers from whom we have taken information are engaged in teaching in the Higher Secondary level. We designed the questionnaire in order to extract information regarding the teaching methodology, facility and logistic support. Thirtyfive teachers from twenty colleges across the country (from different divisions) responded to the research questionnaire. We also held a focused group discussion where thirteen of the thirty-two teachers could participate where they freely expressed their feelings and shared their experiences. We also interviewed 15 teachers grouping them into twoteachers who are recently (within one or two years) graduated aged 24- 27 years and the teachers who are already in the profession for more than one year.

\section{Result and Discussion}

All the participants of our fact-finding sessions agree unanimously that the problem lies in the implementation of the teaching methodology. The point that became highlighted is the appropriateness of some of the aspects of the CLT. But no one was against the approach. In response to the question 7 (Q-7: The communicative approach (CA) is highly feasible for ELT in Bangladeshi context), which was asked for the feasibility of CA, $71.4 \%$ of the participants answered in the negative (disagreed). 
Regarding the teacher training (Question 9), all the participants emphasized on the necessity of it. The vast majority of the teachers $(85.7 \%)$ opted for the blend of ELT methodologies (Question 11). Space does not allow a detailed discussion of everything; however, several issues are worth presenting.

\begin{tabular}{|c|c|c|c|c|c|c|c|}
\hline \multirow{2}{*}{\multicolumn{2}{|c|}{$\begin{array}{l}\text { 1. Two years course is adequate for students to } \\
\text { learn Basic English. }\end{array}$}} & $\begin{array}{l}\text { Strongly } \\
\text { Agree }\end{array}$ & $\begin{array}{l}\text { Slightly } \\
\text { Agree }\end{array}$ & Agree & Disagree & $\begin{array}{c}\text { Slightly } \\
\text { Disagree }\end{array}$ & $\begin{array}{l}\text { Strongly } \\
\text { Disagree }\end{array}$ \\
\hline & & 14.3 & 28.6 & 57 & 0 & 0 & 0 \\
\hline 2. & $\begin{array}{l}\text { The scope of teaching grammar in a com- } \\
\text { municative syllabus is quite narrow. }\end{array}$ & 0 & 0 & 14.3 & 57 & 0 & 28.6 \\
\hline 3. & $\begin{array}{l}\text { The curriculum of English fulfills the instructor's } \\
\text { expectation. }\end{array}$ & 0 & 0 & 14.3 & 57 & 0 & 28.6 \\
\hline \multirow[t]{2}{*}{4.} & \multirow[t]{2}{*}{$\begin{array}{l}\text { The class size generally enables the instruc- } \\
\text { tors to teach English effectively. }\end{array}$} & $\begin{array}{l}\text { Strongly } \\
\text { Agree }\end{array}$ & $\begin{array}{l}\text { Slightly } \\
\text { Agree }\end{array}$ & Agree & Disagree & \begin{tabular}{c|} 
Slightly \\
Disagree
\end{tabular} & $\begin{array}{l}\text { Strongly } \\
\text { Disagree }\end{array}$ \\
\hline & & 0 & 0 & 0 & 28.6 & 0 & 71.4 \\
\hline 5. & $\begin{array}{l}\text { The size and duration allow the instructor to } \\
\text { do the skill-based activities. }\end{array}$ & 0 & 0 & 0 & 28.6 & 14.3 & 57 \\
\hline 6. & $\begin{array}{l}\text { It is quite difficult for the instructor to moti- } \\
\text { vate a learner in an English language class- } \\
\text { room. }\end{array}$ & 14.3 & 28.6 & 28.6 & 14.3 & 14.3 & 0 \\
\hline 7. & $\begin{array}{l}\text { The communicative approach is highly fea- } \\
\text { sible for ELT in Bangladeshi context. }\end{array}$ & 0 & 0 & 28.6 & 28.6 & 14.3 & 28.6 \\
\hline 8. & $\begin{array}{l}\text { The previous method i.e. GTM used to be fol- } \\
\text { lowed in the class was more effective. }\end{array}$ & 14.3 & 14.3 & 0 & 42.8 & 0 & 28.6 \\
\hline & $\begin{array}{l}\text { To implement the communicative approach } \\
\text { successfully in ELT, the teachers training } \\
\text { should be obligatory. }\end{array}$ & 71.4 & 0 & 28.6 & 0 & 0 & 0 \\
\hline 10. & $\begin{array}{l}\text { There are sufficient training programmes and } \\
\text { institutions of the EL teachers in Bangladesh. }\end{array}$ & 0 & 0 & 0 & 57 & 0 & 42.8 \\
\hline & $\begin{array}{l}\text { The blend of ELT methodologies is more ef- } \\
\text { fective in a large class. }\end{array}$ & 42.8 & 0 & 28.6 & 14.3 & 0 & 0 \\
\hline \multirow[t]{2}{*}{12.} & \multirow[t]{2}{*}{$\begin{array}{l}\text { Additional support for ELT outside the class } \\
\text { may be necessary. }\end{array}$} & $\begin{array}{l}\text { Strongly } \\
\text { Agree }\end{array}$ & $\begin{array}{l}\text { Slightly } \\
\text { Agree }\end{array}$ & Agree & Disagree & \begin{tabular}{c|} 
Slightly \\
Disagree
\end{tabular} & $\begin{array}{l}\text { Strongly } \\
\text { Disagree }\end{array}$ \\
\hline & & 42.8 & 14.3 & 42.8 & 0 & 0 & 0 \\
\hline 13. & Accuracy is highly sought from the students. & 14.3 & 28.6 & 28.6 & 28.6 & 0 & 0 \\
\hline & $\begin{array}{l}\text { Memorization plays an important role in } \\
\text { achieving higher percentage. }\end{array}$ & 14.3 & 0 & 71.4 & 14.3 & 0 & 0 \\
\hline 15. & Curriculum focuses equally on all the 4 skills. & 14.3 & 0 & 14.3 & 14.3 & 0 & 57 \\
\hline 16. & $\begin{array}{l}\text { Using literature in a language class-room } \\
\text { might be an effective tool for teaching learn- } \\
\text { ers. }\end{array}$ & 42.8 & 14.3 & 42.8 & 0 & 0 & 0 \\
\hline & $\begin{array}{l}\text { To teach English, the medium of instruction } \\
\text { should be all through in English in the context. }\end{array}$ & 28.6 & 14.3 & 14.3 & 14.3 & 28.6 & 0 \\
\hline 18. & $\begin{array}{l}\text { Different modes of instructor as conferences, } \\
\text { discussion, and peer-work other than lecturer } \\
\text { might prove more effective. }\end{array}$ & 42.8 & 0 & 42.8 & 0 & 0 & 14.3 \\
\hline & $\begin{array}{l}\text { The prescribed text narrows down the scope } \\
\text { of teaching. }\end{array}$ & 28.6 & 42.8 & 0 & 0 & 14.3 & 14.3 \\
\hline & $\begin{array}{l}\text { Keeping lesson plan regularly helps to en- } \\
\text { hance the class standard. }\end{array}$ & 42.8 & 0 & 28.6 & 28.6 & 0 & 0 \\
\hline
\end{tabular}


All the facts that have come up that give a picture of TESL in the college level of Bangladesh have been summarized below:

1. The primary goal of majority of the institutions is to provide education at affordable price to all the levels of people. For this basic reason, the teachers do not have access to the latest technology and research materials for the causes economic as well as geographic. In most cases, these institutions are the sole providers of the education of the remote region that can satisfy only the basic requirements.

2. The problems are varied but mainly related to the level of students, their responsibility and their learning styles. Class size in comparison to the time period of lessons is also significant. Deferential nature of the society also showcases the hindrance in implementing CLT alone in a language classroom.

3. The prevailing examination system is another problem for the CLT. It is more achievement oriented rather than performance oriented. It emphasizes on the grades and positions other than the issues of fluency and accuracy. So, invariably, the teacher becomes or has to become the "facilitator of examinations rather than of linguistic or communicative competence" (Gupta, 2005). Besides, the ongoing system encourages cramming on which the students tend to rely too much.

4. Students do not believe they are the managers of their learning. Neither do they think their teachers 'facilitator' nor do they accept an emphasis on a student-based struggle to communicate. They tend to rely on "pure talkchalk lectures that are mostly teacher-centred" (Gupta, 2005).

5. Teachers also identify that the learners fear the loss of face, shyness and have a reluctance to question the teacher.

6. Responses from the teachers establish the fact that there are certain realms of CLT that raise question on the validity and viability of a number of the central tenets of CLT. All teachers claim to use the approach but have problems in implementing it. It is perhaps the fear of going backwards that has hindered us from exploring other alternatives, which could lead us forward.

We also can better understand of the summarized results/of the fact from the questionnaire from a graphical representation.

\section{Graphical Representation of the Results}

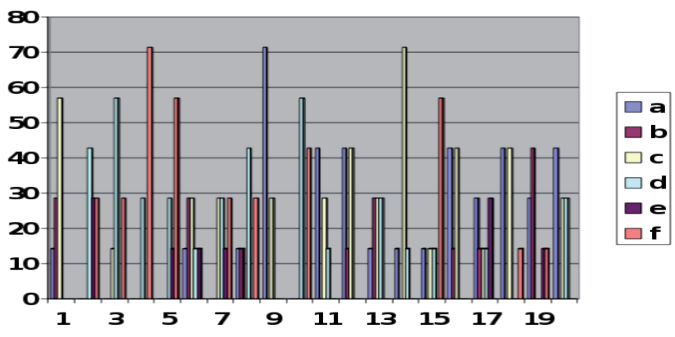

\section{An Alternative Paradigm - Blend of CA and CBA}

Jacobs and Farrell (2001:55) comment that, "When a paradigm shift takes place, we see things form a different perspective as we focus on different aspects of the phenomena”. As when the shift from GMT to CLT occurred, the focus shifts from the structures to the functions. ESL teachers are, nevertheless, increasingly using more communicative approaches to second language teaching. One of the primary characteristics of this approach is a focus on meaning, or as Ellis (2005) recently puts it, that instruction is 'predominantly [focused] on meaning'. One of the reasons for the limited amount of second language learning that occurs in a second or foreign language context is that there is such a limited amount of L2 input provided or available to the learners. Where the teachers speak the first language of the students, there is a great temptation to do much of the explanation in the first language so that during a class of forty minutes, the L2 is heard or read only a small fraction of the total class time. In other words, input provided to learners is frequently quite limited and if we are agreed that input is vital for language development (Ellis, 2005; Krashen, 1994; Lighbown, 2000; VanPatten, 2003), then improved outcomes in our second/foreign language classrooms are more likely to occur if the 
amount of input in the ESL in class is increased substantively. Content-based teaching can be a mode of increasing input of the target language. Here, the content is at the fore in the teaching-learning process. The framework (the following Figure 2) for a CBA argues that the language learners learn best in teaching-learning environments that contain contents that are harmonious with their learning styles and expectations-that is greatly influenced by age and culture. So, where there is predominance and interference of first language in a language classroom, the content-based approach may minimize the effect of L1 and increase the exposure of the target language to the learners. However, the alternative does not negate the view that language is about communication. We, rather, argue for a blend of methodology where the learners will at first get accustomed with the target language (through CBA) and then they will be entrusted with the tasks that enhance the communicative competence.

\section{Suggestions for Policy-Makers}

Fruitful implementation of any teaching methodology is not to do with the ELT practitioners only. The authority concerned and administrative

\section{Figure 2:The Blend of CLT and CBA (Modified from Jarvis, 2004)}

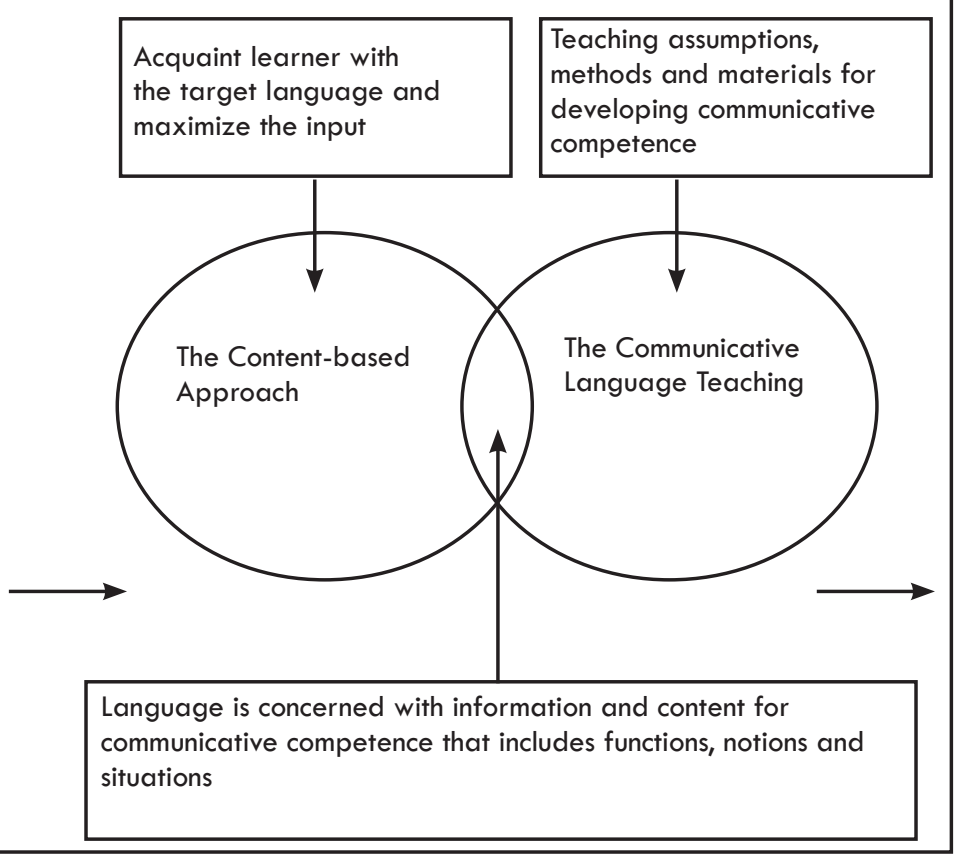

bodies also have a significant role to play. One of the major problems that have been identified in the Bangladeshi context is the lack of appropriate involvement in teaching methodology and guidance of the officials of the Ministry of Education, Education Board, Curriculum Board and the authority of the local college. So, through this paper we are uplifting some ideas that may be pondered on by the authorities:

1. Successful implementation of the teachertraining programmes is useful as teachers are not well-trained before entering into their profession, and this process will give them quality enough to impart their knowledge to teach their pupils.

2. Successful implementation of the monitoring body of the Ministry of Education as most of them does not feel to do their duties properly without supervision.

3. Circulation and insurance of uniform and elaborate instruction regarding teachinglearning process, which enables them better equipped to discharge their duties properly.

4. Considerations of curriculum innovation keeping in mind the insufficiency of facilities, resources and fund as the whole process need to be taken into consideration keeping in mind the socio-economic situation of a country, like Bangladesh.

5. Encouraging and ensuring teachers' adaptability to the teaching procedures with the context as the friendly environment will help the students to learn better.

6. Creating environment where teachers will be receptive to novelty and innovation as the students are not very inquisitive in classes, like Bangladesh, where the social barrier comes into place. 
7. Engineering an evaluation process in accordance with the teaching-learning objective defined beforehand to see the accountability and discharging the duties on the part of the teachers.

8. Reducing class size by increasing sections to an affordable limit where language teaching might be effective as class-size helps teachers to teach the students with adequate ease and help students to learn the lessons properly.

9. Ensuring the use of technology (at least audio player) in every institution as audio-visual aids are very much pertinent in teaching English classes and help students learn English skills properly.

\section{Conclusion}

Much of the debate, regarding CLT, has been focused on the issues of cultural appropriateness of Asian learners (Anderson, 1993; Ellis, 1996; Rao, 2002; Sano et al., 1984) and a number of issues have recently been raised in the Asian EFL Journal (Yoon, 2004; Lin, 2004). Many works have identified problems of implementing the approach within specific contexts, but all ultimately support an "adapted version which takes into account local condition" (Jarvis \& Atsilarat, 2004). More recently Kumaravadivelu's work (2001) attempts a shift in perspective by identifying limitations associated with CLT methodology. Kumaravadivelu argues for a focus on particularity, practicality and possibility. This paper shows that teachers encounter problems with CLT implementation in relation to teaching procedures and learning goals that have much to do with 'particularity, practicality and possibility'.

The challenges faced by the teachers of English are manifold. They face the problem of teaching a class which is large in number of students in comparison of stipulated time to teach, the lack of remuneration paid for them, non-access to latest teaching aids and resource-materials to implement in the classes, the evaluation by the existing exam system, non-participatory attitude of the students, the prevailing social milieu where the students are not appreciative of their inquisitive nature; thus, the proper implementation of the CLT becomes dubious in Bangladeshi context. The above mentioned recommendations will help the policy makers and ELT practitioners and others concerned to overcome these challenges and they can attempt to resort the suitability by implementing them in their concerned spheres.

However, the CA is undoubtedly a very useful paradigm which is why we argue, in this paper, that a CBA alterative needs to be blended with it. The emergence and rise of Indian English, Singapore English, and Australian English etc. only highlight the fact that the 'content' is equally important with 'communication'. So, the CA-CBA might put the English not in the margin of L2/FL but establish it as a global language which is the rightful claim of the inhabitants of today's world. Thus, the challenge for the ELT practitioners is surely with the teachinglearning styles and expectations rather than to try to fit them into any prescribed framework of a model.

Md. Kamrul Hasan is an assistant professor in English at the English Language Institute in United International University, Dhanmondi, Dhaka, Bangladesh. He has been teaching English, Linguistics at different private universities for more than four years. He has presented papers in several international conference, including paper presented in Nepal, Malaysia, Thailand, Philippines, and Bangladesh. He has earned M Phil and M.A degrees in Linguistics and B.A (Hons) in English from University of Delhi, India. His professional interests include ELT, Sociolinguistics, Linguistics and SLA.

Mohd. Moniruzzaman Akhand has been associated as lecturer in the department of English of Eastern University, Dhanmondi, Dhaka, Bangladesh. He has been teaching English, Applied Linguistics and ELT for more than two years. He has presented papers in three international conferences. He has been graduated from the Department of English, University of Dhaka, Bangladesh having major in Applied Linguistics and ELT. His interests cover ELT, SLA and issues of Teacher Development.

\section{Reference}

Anderson, J. (1993). Is a communicative approach practical for teaching English in China? Pros and cons. System, 21 (4): 471-480.

Bachman, L. (1991). Fundamental considerations in language testing. Oxford: OUP

Bowers, R. (1983). Project planning and performance. London: British Council.

Breen, M., \& Candlin, C. N. (1980). The essentials of a communicative curriculum in language teaching. Applied Linguistics 1(2): 89-112. 
Brinton, D. M., Snow, M. A. \& Wesche, M. B. (1989). Contentbased second language instruction. New York: Newbury House.

Brumfit, C. J., \& Johnson, K. (eds.) (1979). The communicative approach to language teaching. Oxford: OUP.

Canale, M. \& Swain, M. (1980). Theoretical bases of communicative approaches to second language teaching and testing. Applied Linguistics 1(1): 1-47

Candlin, C. N. (1976). Communicative language teaching and the debt to pragmatics. Washington, D. C.: GUP.

Celce-Murćia, Dörnyei, M. A. \& Thurell, S. (1997). Direct approaches in L2 instruction: A turning point in Communicative Language Teaching? TESOL Quarterly 31 (1): 141-152.

Chomsky, N. (1957). Syntactic structures. The Hague: Mouton.

Chomsky, N. (1965). Aspects of the theory of syntax. Cambridge: MIT Press.

D’Anglejan, A. \& Tucker, R. (1975). The acquisition of complex English structures by adult learners. Language Learning 25 (2): 281-296.

Ellis, G. (1996). How culturally appropriate is the communicative approach? ELT Journal, 57 (3): 278287.

Ellis, R. (2005). Principles of instructed language learning. System, 33 (2): 209-224.

Gupta, D. (2005). ELT in India: A brief historical and current overview. Asian EFL Journal, Volume 7, Issue 1, Article 12.

Halliday, M. A. K. (1970). Language structure and language function. In J. Lyons (ed.), New Horizons in Linguistics. Harmondsworth: Penguin.

Hymes, D. (1972). On communicative competence. In J. B. Pride and J. Holmes (eds.), Sociolinguistics. Harmondsworth: Penguin.

Jacobs, G. \& Farrell, T. (2001). Paradigm shift: Understanding and implementing change in second language education' in http://www.-writing.berkeley.edu/ TESL-EJ.

Johnson, K. (1982). Communicative syllabus design and methodology. Oxford: Pergamon.

Krahnke, K. (1987). Approaches to syllabus design for foreign language teaching. New York: Prentice Hall.

Krashen, S. (1994). The input hypothesis and its rivals. In N. Ellis (ed.), Implicit and explicit learning of languages. New York: Academic Press.
Kumaravadivelu, B. (2001). Towards a postmethod pedagogy. TESOL Quarterly, 35 (4): 537-559.

Lighbown, P. M. (2000). Classroom SLA research and second language teaching'. Applied Linguistics, 21 (4): 431462.

Littlewood, W. (1981). Communicative language teaching. Cambridge: CUP.

Littlewood, W. (1984). Foreign and second language learning: Language acquisition research and its implications for the classroom. Cambridge: CUP.

Mohan, B. (1986). Language and content. Reading, Mass: Addison-Wesley.

Nicholls, A. (1983). Managing educational innovations. London: Allen and Unwin.

Richards, J. C. \& Rodgers, T. S. (2001). Approaches and methods in language teaching. Cambridge: CUP.

Stryker, S. \& Leaver, B. (1993). Content-based instruction in foreign language education. Washington: GUP.

White, R. V. (1993). The ELT curriculum. Oxford: Blackwell Publishers.

Widdowson, H. G. (1972). The teaching of English as communication. English Language Teaching 27 (1): 15-18.

Widdowson, H. G. (1978). Teaching language as communication. Oxford: OUP.

Wilkins, D. A. (1972). The linguistics and situational content of the common core in a unit/credit system. MS Strasbourg: Council of Europe.

Wilkins, D. A. (1976). Notional syllabuses. Oxford: OUP.

Wu, S.-M. (1996). Content-based ESL at high school level: A case study'. Prospect 11 (1): 18-36.

Jarvis, H. \& Atsilarat, S. (2004). Shifting paradigms: from a communicative to a context-based approach. Asian EFL Journal Volume 6, Issue 4, Article 8.

Rao, Z. (2002). Chinese students' perceptions of communicative and non-communicative activities in EFL classroom. System, 30 (1): 85-105.

Sano, M., Takashi, M. \& Yoneyama, A. (1984). CLT and local needs. ELT Journal, 38 (3): 170-176.

Van Patten, B. (2003). From input to output: A teacher's guide to second language acquisition. New York: McGrawHill. 